\title{
Consumption and Participation to Culture among the European Youth
}

\author{
Oana Parvu \\ Research Institute for Quality of Life \\ Cristina_oana_parvu@yahoo.com
}

\begin{abstract}
Culture defines a society's identity and pegs its history with benchmarks, codes, norms and models, attitudes about life and knowledge products full of symbols. A number of researches into cultural anthropology have highlighted the distinct role culture plays in the process of building and maintaining the balance both at social and individual levels. Part of one's identity, culture is also embedded into one's quality of life. in the same time, the culture playing "a substantial role in adolescent development. Development scientists have shown increasing interest in how culture and religion are involved in the processes through which adolescents adapt to environments."1. This paper is made and published under the aegis of the Research Institute for Quality of Life, Romanian Academy as a part of programme co-funded by the European Union within the Operational Sectorial Programme for Human Resources Development through the project for Pluri and interdisciplinary in doctoral and post-doctoral programmes Project Code: POSDRU/159/1.5/S/141086
\end{abstract}

Keywords: Culture, identity, anthropology, quality of life, adolescent,

\section{Introduction}

Few big social researches commissioned by the European Commission have been conducted across the EU countries to study the cultural consumption and participation to culture amongst youth (aged 15 to 24). The special Eurobarometer 399 on 'Cultural Access and Participation' with data collected in April-May 2013 offers valuable information on the topic showcasing different levels of engagement with culture by age groups. The study measured youth access and participation to a set of cultural activities such as following TV and radio cultural shows, going to historical monuments, going to the cinema, concert, theatre. The research also identifies the main barriers to accessing culture for youth, the level of using the internet for cultural purposes and participation to cultural exchange programs.

This survey was conducted by TNS Opinion and Social network in 27 European Countries and Croatia, using eurobarometer interviews surveys, as methodology, and 26,563 respondents were interviewed at their place, face to face in their mother tongue. The Eurobarometer 399 on 'Cultural Access and Participation' came as a continuation of initiatives taken after the Agenda for Culture (2007) which had as objectives that "the cultural sector and EU institution to jointly promote:

-cultural diversity and intercultural dialogue

- culture as a catalyst for creativity for growth and jobs

- culture as a vital element in the Union's international relations"2

in the same time this research was made to see the changes that took place in domain of participation to culture in comparison with the findings of the Special Eurobarometer 278 on 'European Cultural Values' for which data had been collected in February-March 2007.

The Special Eurobarometer 278 from 2007 was realized also by TNS Opinion and Social Network, the number of respondents being 26755 from $27 \mathrm{EU}$ countries. The methodology was also eurobarometer, the authority which carried it out was the Directorate General for Communication (Unit for Public Opinion and Media Monitoring).

One of the main findings of the Special Eurobarometer 278 "European Cultural Values" European Youth (age 15-24) was that the associated the term of "culture" more with Arts (performance arts and visual arts) $34 \%$ than with traditions,

1 Trommsdorff G., Chen X.(2012) - "Values, Religion and Culture in Adolescent Development", Cambridge University Press 2 European Comission (co-ordinated) -Special Eurobarometer 399 "Cultural Access and Participation" (2013)p.2 source:

http://ec.europa.eu/public_opinion/archives/ebs/ebs_399_en.pdf 
languages, customs and social or cultural communities $-28 \%$, also than literature, poetry, playwriting, authors $-20 \%$ from the total of youth. 1

As a general view over the differences between data obtained at the end of these two researches, it is noticed a decrease in the participation to culture of European citizens on most of dimensions and indicators as: watching or listened to a cultural program on TV or on the radio at least once (72\% in 2013 compared to $78 \%$ in 2007 , reading a book at least once $68 \%$ in 2013 compared to $71 \%$ in 2007), visiting a historical monument or site at least once ( $52 \%$ in 2013 compared to $54 \%$ in 2007),visiting a museum or a gallery at least once (37\% in 2013 compared to $41 \%$ in 2007), being to a concert at least once (35\% in 2013 compared to $37 \%$ in 2007), visiting a public library at least once (31\% in 2013 compared to $35 \%$ in 2007 ), being to the theatre at least once (28\% in 2013 compared to $32 \%$ in 2007). The same values were obtained regarding seeing a ballet, a dance performer or an opera at least once (18\%) and about being to the cinema at least once, the rate of participation in 2013 were more than in 2007 (52\% in 2013 than 51\% in 2007). The report notes that "this decline might be partly an effect of the financial and economic crises."2

in this general context, the consumption and participation to culture among the youth in Europe (age 15-24), take a specific form.

At the question: "How many times in the last 12 months have you watched or listen to a cultural programme on TV or on the radio? " (Table 1) $27 \%$ from age $15-24$ respondents, didn't watch or listen cultural programme but $35 \%$ watched or listened cultural programme more that 5 times, the fewer from the all category of ages, $72 \%$ watched or listened TV or radio cultural programmeat least once in last year, on the second in the hierarchy of the other categories of ages, with $1 \%$ lower that $40-45$ ages category.

In the report from 2013 is mentioned that similar pattern was revealed in the context of reading books. in 2007, the rate of this category of youth (15-24 age) who read books last year, was of of $82 \%$ which was the highest rate of all the other categories of ages.

At the question "How many times in the last 12 months have you been to the cinema?", the European youth were the most of all categories of age that had been more that 5 times - 30\% compared to age 25-39 respondents (17\%), to age 40-54 respondents (11\%) and age 55+ respondents (only 6\%) - Table 2. in 2013 the rate of youth (15-24 ages) that had been to the cinema at least once is $80 \%$, with $2 \%$ lower than in 2007 (82\%).

Participation of European citizens to a concert, according to the research, is very low. in the same time, the youth had been to a concert more often than the other category of ages $6 \%$ of them had been to a concert for more than 5 times, $49 \%$ hadn't been at all in the last 12 months, $33 \%$ of them had been to a concert for more than 3-5 times in last 12 months. Table 3. Compared to 2007, the percent of this category of youth that had gone to a concert at least once in last year, is almost similar, lower by only $1 \%$ ( $52 \%$ in 2007 versus $51 \%$ in 2013 ).

At the question "How many times in the last 12 months have you been to the theatre?" $32 \%$ of youth (15-24 ages) had been to the theatre at least once, compared to $27 \%$ of the $25-39$ aged and the $40-54$ aged respondents $(30 \%)$ or the $55+$ aged (25\%).- Table 4 . There is a slight decrease of 3pct points of the youth going to the theatre in the last year from $35 \%$ in 2007 to $32 \%$ in 2013.

As a partial conclusion it can be noticed that, from all cultural activities, done at least once in last 12 months, European youth (15-24 ages) prefer the most to go tp the cinema $(80 \%)$, then watching or listening a TV or radio cultural programs $(72 \%)$, on the third place, going to a concert $(51 \%)$ and on the last place going to a theatre $(32 \%)$.

in the same time the participating of European youth (15-24 ages) to cultural activities in 2013 was lower that in 2007, but the percent of differences wasn't so big.

Another dimension measured by the research was "barriers to accessing culture".

The main reason the European youth did not participate more often in cultural activities is lack of interest, particularly for ballet/ dance performer/ opera $(60 \%)$ or theatre $(46 \%)$. for youth, price is more of a barrier to access theatre $(18 \%)$ while

1 Special Eurobarometer 278 "European Cultural Values" - TNS Opinion \& Social - survey requested by Directorate General Education and Culture, coordinated by Directorate General Communication (2007) p.8 source:

http://ec.europa.eu/public_opinion/archives/ebs/ebs_278_en.pdf

2 Special Eurobarometer 399 "Cultural Access and Participation" European Comission (co-ordiated) (2013) p.5 source:

http://ec.europa.eu/public_opinion/archives/ebs/ebs_399_en.pdf 
the main reasons for not visiting historical monuments are - to a similar extent - lack of interest and lack of time (35\%).Table 5,6,7.

Another goal of the survey was to measure the access to and participation in non-national cultural activities:

In this context, the percent of European youth (15-24 age) who in last 12 months had read "at least" one book by an author from another European country was the biggest of all the ages categories, 38\%, compared to 33\% (ages 24-39), to 32\% (ages $40-54$ ), $26 \%$ (ages $55+$ ). 1

It happened the same with the answer of question:" How many times in the last 12 months have you watched or listened to a cultural programme on TV or on radio from another European country", the percent of European youth, $31 \%$, was the biggest of all the other categories of ages.

The data obtained after addressing question:" How many times in the last 12 months have you visited a historical monument or site (palaces, castles, churches, gardens, etc) in another EU country are very close one to the other regarding all the categories of ages $22 \%$ (ages 15-24), 21\% (ages 25-39), 21\% (ages 40-54), and less for the category of 55+ages only $16 \% .2$

As we can notice, the rate of European youth who had read a book written by a foreign author are the highest from all the others $(38 \%)$, being followed by watching or listening TV or radio programme from another EU country (31\%), and by visiting a monument or site in another EU country.

Regarding the Involvement in artistic activities for the 15-24 ages respondents, $45 \%$ of them said spontaneous that are not involved in none artistic activities, $23 \%$ said that are involved in dancing and $18 \%$ said that they made a film or done some photography. $16 \%$ had sung, also $16 \%$ played to a musical instrument, $15 \%$ had done creative computing such as designing, websites or blogs, etc, $11 \%$ had written a poem, an essay, a novel, $6 \%$ had acted on the stage or in a film. The same, they are the most involved in artistic activities than all the other categories of age, participation decreasing in the same time with increasing of age. 3

In 2007 the artistic activity which had the highest rate of European youth participation(age 15-24) was photography/film $(31 \%)$ followed by dance $(29 \%)$ and decorating, handicrafts,gardening $(29 \%)$, writing something $(21 \%)$, singing $(21 \%)$, playing a musical instrument (17\%), acting (9\%).4

Also in this case we can notice that the rate of youth involvement in artistic activities, in 2013 is lower than in 2007 for each type of activity considered.

Another dimension researched in the survey was using the internet for cultural purposes.

The answers the question:" How often do you use the Internet for cultural purpose like, for instance, searching for cultural information, buying cultural products, or reading articles related to culture?" revealed that European youth (age 15-24) use the internet in percent of $44 \%$ at least once a week, the biggest percent of all the others categories of ages. $53 \%$ of European youth (15-24 age) use internet for listening to radio or music and $50 \%$ for downloading music, compared to the other categories of ages that use internet the most for reading the newspaper or articles online. 5

As a conclusion the European youth (age 15-24) participate more than the other categories of ages in many and various cultural activities.

All the survey data were and for sure will be very important in creating and implementation of cultural policies at European level and also in each of the member countries, taking into consideration the importance of culture and creativity, well underlined as a quotation in the Introduction of Special Eurobarometer 278 (2007):

1 Special Eurobarometer 399 "Cultural Access and Participation" European Comission (co-ordiated) (2013) p.44 source: http://ec.europa.eu/public_opinion/archives/ebs/ebs_399_en.pdf

2 Special Eurobarometer 399 "Cultural Access and Participation" European Comission (co-ordiated)(2013) p.46

3 Special Eurobarometer 399 "Cultural Access and Participation" European Comission (co-ordiated) (2013) p.53 source:

http://ec.europa.eu/public_opinion/archives/ebs/ebs_399_en.pdf

4 Special Eurobarometer 278 "European Cultural Values" - TNS Opinion \& Social - survey requested by Directorate General Education and Culture, coordinated by Directorate General Communication (2007) p.23 source:

http://ec.europa.eu/public_opinion/archives/ebs/ebs_278_en.pdf

5 Special Eurobarometer 399 "Cultural Access and Participation" European Comission (co-ordiated) (2013)p.60 source:

http://ec.europa.eu/public_opinion/archives/ebs/ebs_399_en.pdf 
"Culture and creativity are important drivers for personal development, social cohesion and economic growth. Today's strategy promoting intercultural understanding confirms culture's place at the heart of our policies."1

\section{References:}

[1] Special Eurobarometer 399 "Cultural Access and Participation" European Comission (co-ordinated) (2013)source: http://ec.europa.eu/public_opinion/archives/ebs/ebs_399_en.pdf

[2] Special Eurobarometer 278 "European Cultural Values" - TNS Opinion \& Social - survey requested by Directorate General Education and Culture, coordinated by Directorate General Communication (2007) source: http://ec.europa.eu/public_opinion/archives/ebs/ebs_278_en.pdf

[3] Trommsdorff G., Chen X.- "Values, Religion and Culture in Adolescent Development", (2012) Cambridge University Press

\section{Tables}

Tabel 1: "How many times in the last 12 months have you watched or listen to a cultural programme?"

Source: European Comission (co-ordinated) -Special Eurobarometer 399 "Cultural Access and Participation" p.13

$\begin{array}{lllll}\text { Not in the last } 12 \text { months } & \begin{array}{l}1-2 \\ \text { times }\end{array} & 3-5 \text { times } & \text { More than } 5 \text { times } & \text { Don't know } \quad \begin{array}{l}\text { Total "at least } \\ \text { once" }\end{array}\end{array}$

$\begin{array}{lllllll}\text { Age } & & & & & \\ \\ 15-24 & 27 \% & 21 \% & 16 \% & 35 \% & 1 \% & 72 \% \\ 25-39 & 28 \% & 19 \% & 13 \% & 39 \% & 1 \% & 71 \% \\ 40-54 & 26 \% & 15 \% & 16 \% & 42 \% & 1 \% & 73 \% \\ 55+ & 28 \% & 13 \% & 14 \% & 44 \% & 1 \% & 71 \%\end{array}$

http://ec.europa.eu/public_opinion/archives/ebs/ebs_399_en.pdf

Table 2: "How many times in the last 12 months have you been to the cinema?"

Not in the last $1-2$ times $\quad 3-5$ times $\quad$ More than 5 times $\quad$ Don't know $\quad \begin{aligned} & \text { Total "at least } \\ & 12 \text { months }\end{aligned}$

Age

$\begin{array}{lllllll}15-24 & 20 \% & 24 \% & 26 \% & 30 \% & - & 80 \% \\ 25-39 & 33 \% & 30 \% & 20 \% & 17 \% & - & 67 \% \\ 40-54 & 46 \% & 26 \% & 17 \% & 11 \% & - & 54 \% \\ 55+ & 72 \% & 14 \% & 7 \% & 6 \% & 1 \% & 27 \%\end{array}$

Source: European Comission (co-ordinated) -Special Eurobarometer 399 "Cultural Access and Participation" p.16 http://ec.europa.eu/public_opinion/archives/ebs/ebs_399_en.pdf

Tabel 3 : "How many times in the last 12 months have you been to the concert?"

1 Special Eurobarometer 278 "European Cultural Values" - TNS Opinion \& Social - survey requested by Directorate General Education and Culture, coordinated by Directorate General Communication (2007) p.3 source:

http://ec.europa.eu/public_opinion/archives/ebs/ebs_278_en.pdf quotation from

http://ec.europa.eu/culture/eac/communication/comm_en.html 


$\begin{array}{llll}\text { Not in the last } 12 \text { months } & \begin{array}{l}1-2 \\ \text { times }\end{array} & 3-5 \text { times } \quad \text { More than } 5 \text { times } \quad \text { Don't know }\end{array}$

Age

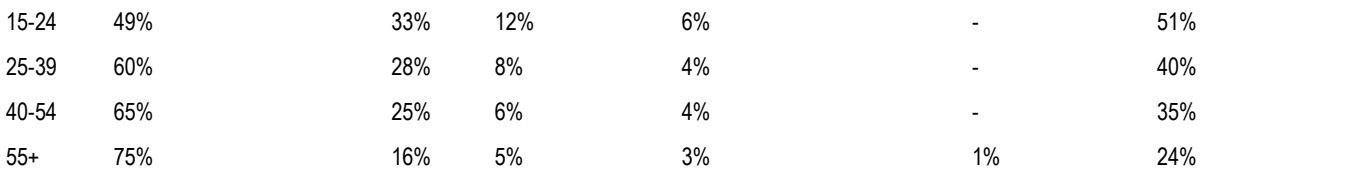

Source: European Comission (co-ordinated) -Special Eurobarometer 399 "Cultural Access and Participation" p.18

http://ec.europa.eu/public_opinion/archives/ebs/ebs_399_en.pdf

Table 4: "How many times in the last 12 months have you been to the theatre?"

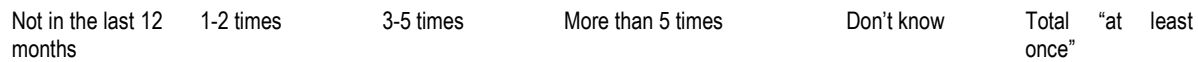

Age

\begin{tabular}{|c|c|c|c|c|c|c|}
\hline $15-24$ & $68 \%$ & $24 \%$ & $5 \%$ & $3 \%$ & - & $32 \%$ \\
\hline $25-39$ & $72 \%$ & $20 \%$ & $5 \%$ & $2 \%$ & $1 \%$ & $27 \%$ \\
\hline $40-54$ & $70 \%$ & $21 \%$ & $6 \%$ & $3 \%$ & - & $30 \%$ \\
\hline $55+$ & $74 \%$ & $17 \%$ & $5 \%$ & $3 \%$ & $1 \%$ & $25 \%$ \\
\hline
\end{tabular}

Source: European Comission (co-ordinated) -Special Eurobarometer 399 "Cultural Access and Participation" p.19 http://ec.europa.eu/public_opinion/archives/ebs/ebs_399_en.pdf

Table 5:

Question:"And for each of the following activities, please, tell me why you haven't done it more often in the last 12 months?" the responses of youth had: Seen a ballet, a dance performance or an opera

Lack of interest

Too expansive

$$
\begin{aligned}
& \text { Limited choice or } \\
& \text { poor quality of this } \\
& \text { activity in the place } \\
& \text { where you live }
\end{aligned}
$$$$
\text { Lack of of }
$$

Age

$\begin{array}{llllll}15-24 & 60 \% & 15 \% & 11 \% & 8 \% & 3 \% \\ 25-39 & 48 \% & 24 \% & 14 \% & 9 \% & 2 \% \\ 40-54 & 47 \% & 22 \% & 15 \% & 10 \% & 2 \% \\ 55+ & 47 \% & 12 \% & 16 \% & 12 \% & 2 \%\end{array}$

Source: European Comission (co-ordinated) -Special Eurobarometer 399 "Cultural Access and Participation" p.32 http://ec.europa.eu/public_opinion/archives/ebs/ebs_399_en.pdf

Table 6

Been to the theatre

Lack of interest

Lack of time

$19 \%$

$18 \%$
Limited choice or poor quality of this activity in the place where you live
Lack of of information

$4 \%$ 


$\begin{array}{llllll}25-39 & 34 \% & 29 \% & 21 \% & 10 \% & 3 \% \\ 40-54 & 32 \% & 27 \% & 21 \% & 12 \% & 3 \% \\ 55+ & 36 \% & 15 \% & 20 \% & 14 \% & 2 \%\end{array}$

Source: European Comission (co-ordinated) -Special Eurobarometer 399 "Cultural Access and Participation" p.34 http://ec.europa.eu/public_opinion/archives/ebs/ebs_399_en.pdf

Table 7

Visited a historical monument or site (palaces, castles, churches, gardens, etc

$$
\text { Lack of interest Lack of time Too expansive }
$$

Limited choice or

poor quality of this

activity in the place

where you live

Age

$\begin{array}{lll}15-24 & 35 \% & 35 \% \\ 25-39 & 45 \% & 25 \% \\ 40-54 & 45 \% & 22 \% \\ 55+ & 25 \% & 31 \%\end{array}$

Source: European Comission (co-ordinated) -Special Eurobarometer http://ec.europa.eu/public_opinion/archives/ebs/ebs_399_en.pdf

Lack of of information

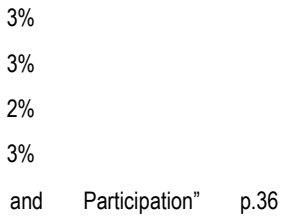

399 "Cultural Access and Participation" p.36

$9 \%$

$8 \% \quad 2 \%$

$9 \% \quad 3 \%$ 